\title{
W krzywym zwierciadle: propagandowa funkcja biuletynów samorządowych
}

$T_{\text {tom }}$ eza zawarta w tytule artykułu może wydawać się w dwadzieścia lat po zmianie systemu politycznego oraz upadku cenzury prewencyjnej w Polsce nieco dyskusyjna, a nawet budząca kontrowersje, jednak - zdaniem autora - stanowi ona odzwierciedlenie istniejącej obecnie sytuacji. Realizacja idei decentralizacji władzy publicznej w III RP służyć miała upodmiotowieniu obywateli. Koncepcja ta zakładała przeniesienie wielu istotnych uprawnień decyzyjnych na niższe szczeble struktury instytucji zarządzających państwem, najpierw na poziom gmin, w dalszej perspektywie na szczebel powiatów i województw samorządowych. Istotą owych zmian było przekazanie społecznościom lokalnym oraz wyłonionym przez nie na ich terenie władzom samorządowym prawa do samostanowienia o swoim losie $\mathrm{w}$ ramach istniejącego porządku prawnego $\mathrm{i} \mathrm{w}$ granicach wytyczonych przez owe przepisy. Sądzono bowiem nie bez podstaw, że taki system decyzyjny, w którym współuczestniczyć będą lokalni decydenci wespół z obywatelami, zmniejszy opór mieszkańców jednostek samorządowych wobec trudnych i kosztownych społecznie przedsięwzięć, a nade wszystko charakteryzował się będzie znacznie większą racjonalnością w wydatkowaniu funduszy publicznych. Liczono przy tym na metamorfozę dotychczasowych złych wzorców w komunikowaniu społecznym, utrudniających w przeszłości wytworzenie wspólnoty informacji i opinii na linii władza-obywatel. Dawny model komunikacji opierał się na założeniu, że to obywatel jest dla państwa, a nie państwo dla obywateli. Takie przedmiotowe traktowanie znajdywało odzwierciedlenie $\mathrm{w}$ relacjach komunikacyjnych, które opierały się z reguły na jednokierunkowym przepływie komunikatów (z góry na dół i przybierały postać nakazów, zakazów, wezwań itd.), wszechobecnej cenzurze prewencyjnej i propagandzie. Wszystkie wspomniane formy aktywności na polu komunikacji stanowiły gwarancję utrzymania przez ówczesne gremia rządzące posłuchu wśród obywateli. Na skutek zakrojonych na dużą skalę działań manipulacyjnych w sferze informacji społeczeństwo nie dysponowało wiedzą adekwatną do rzeczywistości, a przez to niezbędną do podejmowania racjonalnych decyzji.

Wraz ze zmianami demokratyzującymi polski system polityczny odejść miały do przeszłości stare praktyki, bez których realizacja wielu ważnych celów stałaby się wreszcie możliwa. Integralnym elementem nowego modelu współistnienia nie tylko na poziomie samorządu lokalnego miało być osiaganie porozumienia pomiędzy decydentami a zarządzanymi przez nich społecznościami w drodze permanentnej debaty publicznej. Jej treścią miały być istotne dla obywateli sprawy oraz problemy nurtujące uwagę lokalnej opinii społecznej. W tym celu nowe elity władzy powinny wyrzec się obecnej w poprzednim systemie rządów chęci skrywania przed obywatelami niewygodnych dla siebie spraw, wstydliwych zachowań patologicznych towarzyszących przecież ludziom władzy w każdym bez wyjątku systemie politycznym czy manipulowania informacjami niezbędnymi do postawienia wyważonej diagnozy sytuacji i podjęcia racjonalnej decyzji. 
Realizacji tak zakreślonych celów służyć miały między innymi powstające po 1989 roku biuletyny samorządowe oraz lokalna prasa niezwiązana $\mathrm{z}$ instytucjami samorządu terytorialnego. Przedmiotem niniejszych rozważań jest pierwszy z wymienionych segmentów prasy, który z założenia w największym stopniu mógł wypełniać ważną rolę komunikatora wśród społeczności lokalnej. Podstawą owych ogromnych możliwości były między innymi najszerszy dostęp do informacji o działaniach organów władzy lokalnej i podległych jej jednostek, bezpośredni kontakt członków redakcji z przedstawicielami lokalnych elit oraz, na ogół, rozległa wiedza o funkcjonowaniu tworzonych na nowo w Polsce instytucji samorządowych. Po dwóch dekadach obserwacji działań wielu tego typu periodyków widać, że prasa samorządowa stała się niespełnioną obietnicą, a jej głównym celem uczyniono promocję miejscowych notabli bez względu na ich zasługi w działalności na rzecz społeczności lokalnej. Intencją autora jest wykazanie, że funkcja propagandowa stała się obecnie kluczową w funkcjonujących na polskim rynku prasy lokalnej biuletynach wydawanych przez organy samorządowe lub podległe im bezpośrednio jednostki. W efekcie doprowadziło to w wielu wypadkach do wyraźnego ograniczenia dwustronnej komunikacji społecznej w gminach i rozwoju oddziaływań o charakterze dezinformacji. Poprzez skupienie uwagi na oddziaływaniach propagandowych zatracone zostały z pola widzenia określone przed dwudziestu laty zasadnicze cele nowego porządku społecznego i ładu w zakresie komunikowania pomiędzy władzą a obywatelami.

$* * *$

Restytucja samorządu terytorialnego w 1990 roku sprzyjała powstawaniu prasy lokalnej, w tym samorządowych biuletynów informacyjnych. Tego typu periodyki stanowiły od samego początku, według różnych autorów, od około 42 do 60 procent wszystkich wydawanych druków przez lokalne władze ${ }^{1}$. Niestabilność w tym segmencie prasy stanowiła w tamtym czasie naturalną cechę, czego dowodem były okresowe nieznaczne wahnięcia ilościowe. Dla przykładu, w 1994 roku część pism lokalnych finansowanych przez organy samorządu terytorialnego upadła, ale jednocześnie na rynku pojawiło się wiele innych tytułów. Bezpośrednią przyczyną były przeprowadzone w tym roku wybory do rad gmin. Nowe władze nie zawsze akceptowały formułę lub treści ukazujących się podczas poprzedniej kadencji tytułów i wstrzymywały dla nich wszelką pomoc finansową. W tym kontekście należy wskazać na pewną niepokojącą tendencję, towarzyszącą wspieraniu przez samorząd lokalny tego typu pism.

Uzależnienie finansowe, sprzętowe i lokalowe redakcji od samorzadów terytorialnych niejednokrotnie osłabiało prezentowanq na lamach krytyke wobec negatywnych poczynań rad $i$ zarzqdów gmin. Ta swego rodzaju „dyspozycyjność” wobec wtadz odbijata sie jednak negatywnie na zaufaniu czytelników do pisma i jego percepcji w środowisku lokalnym. W ten sposób z ,gazety” podporzqdkowany tytut stawat się w odczuciu odbiorców biuletynem urzędowym, mniej obiektywnym, krytycznym i niezależnym, a przez to również mniej ciekawym².

${ }^{1}$ R. Kowalczyk, Prasa lokalna w systemie komunikowania społecznego, Poznań 2003, s. 141 i n. Jan Załubski powołując się na dane OBP UJ w Krakowie szacował liczbę pism samorządowych na 42 procent rynku prasy lokalnej (J. Załubski, Stowarzyszenie Prasy Lokalnej - kontynuacja dobrych tradycji, w: Z dziejów prasy wielkopolskiej XIX-XX wieku, pod red. M. Kosmana, t. 2, Poznań 1995, s. 139). Z kolei Sylwester Dziki w analogicznym okresie oceniał potencjał prasy wydawanej i finansowanej przez władze lokalne na 45,5 procent (S. Dziki, Media lokalne i regionalne, w: Dziennikarstwo i świat mediów, pod red. Z. Bauera, E. Chudzińskiego, Kraków 1996, s. 88).

${ }^{2}$ W. Adamczyk, Media masowe w procesie budowania demokracji w Polsce (1989-1995), Poznań 1999, s. 163. 
Przyczyn takiej sytuacji upatrywać można nie tylko w niskim poziomie kultury politycznej nowych elit władzy na poziomie lokalnym, ale również w ,starych” nawykach traktowania tego typu periodyków wyniesionych z poprzedniego okresu. Krótkotrwały okres tranzycji systemowej był w tamtym czasie niewystarczający do wyrobienia nowego, zgodnego z istotą demokratycznego współistnienia modelu komunikowania. W tym kontekście nie sposób nie wspomnieć także o twórcach ówczesnej prasy samorządowej. Od samego początku jej istnienia po 1989 roku członkowie redakcji biuletynów samorządowych rekrutowali się spośród nauczycieli gminnych szkół, bibliotekarzy, pracowników placówek kulturalnych, urzędników jednostek gminnych oraz członków organów władzy lokalnej, a więc osób w różny sposób powiązanych z aktualnym establishmentem gminy. Rzadkością było posiadanie wykształcenia dziennikarskiego, nie wszyscy mogli pochwalić się również dyplomem uczelni wyższej. W efekcie poziom merytoryczny poszczególnych pism samorządowych był odzwierciedleniem składów redakcji. Brak fachowego przygotowania do zawodu, doświadczenia oraz niezbędnego $\mathrm{w}$ tej profesji poczucia misji skutkował utratą niezależności od firmujących te wydawnictwa swoją nazwą organów władzy lokalnej. Źródłem owego podporządkowania politycznym decydentom gminnym była też specyfika funkcjonowania biuletynów samorządowych.

Uzależnienie dziennikarza w tym przypadku polega na petnej dyspozycyjności wobec decydenta, która sprowadza się w zasadzie do powstrzymywania się od krytyki jego poczynań. Wiaże się to z przedmiotowym, niemalize instrumentalnym traktowaniem pism, jako tuby chwalacej działalność władz lokalnych. Specyfika pracy dziennikarza pracujacego w piśmie lokalnym zwiqzana jest również z szeregiem powiazań zawodowych, towarzyskich, a nawet rodzinnych, z których niejednokrotnie trudno jest mu się uwolnić. Dotyczy to w równej mierze osób piszacych dla tytutów uważajacych się za niezależne, jak $i$ periodyków samorzqdowych. W sytuacjach konfliktowych podjęcie krytyki osób piastujacych wysokie stanowiska $w$ hierarchii miasta czy gminy, w której dziennikarz mieszka i pracuje, wymaga odwagi cywilnej. A tej często brakuje, przez co pisma, głównie samorzadowe, zamiast odzwierciedlać obiektywne (a zatem $w$ równej mierze pozytywne, jak $i$ krytyczne) opinie o działaniach władz, instytucji czy też podmiotów gospodarczych, skupiaja się na sprawach z punktu widzenia lokalnej społeczności drugorzędnych ${ }^{3}$.

Pomimo upływu dwóch dekad stopień zależności osób redagujących i publikujących w biuletynach samorządowych wobec politycznych decydentów nie zmniejszył się. Znajduje to swoje odbicie w widocznych w praktyce redakcyjnej deformacjach w zakresie realizowania funkcji przypisywanych prasie lokalnej. W literaturze przedmiotu (S. Sobol, B. Gołębiowski, J. Mądry) wymienia się najczęściej kilka funkcji prasy lokalnej (informacyjna, postawotwórcza, organizatorska, interwencyjna, integracyjna, rozrywkowo-rekreacyjna), które na ogół pokrywają się z funkcjami mediów ${ }^{4}$. Znacznie bogatszy katalog powinności nałożonych na periodyki lokalne przedstawił Włodzimierz Chorązki:

\footnotetext{
${ }^{3}$ Ibidem, s. 165. Zob. M. Gierula, Polska prasa lokalna 1989-2000. Typologia i spoleczne funkcjonowanie, Katowice 2005, s. 112-114. M. Gierula tak pisze o zagrożeniu wiarygodności biuletynu samorządowego: W przypadku władzy lokalnej opanowanej przez jednq opcję polityczna pismo samorzqdowe spetnia także często zadania propagandowe i popularyzatorskie samej władzy. Jest to szczególnie widoczne w okresie przed wyborami samorzqdowymi, kiedy pismo niejednokrotnie stanowi wręcz ,"tubę” propagandowq władzy. Bywa to bardzo niekorzystne dla samej idei prasy samorzqdowej, gdyż takie czasopismo po okresie wyborczym traci wiarygodność, a tym samym przestaje być w ogóle skuteczne.

${ }^{4}$ M. Szulczewski, Prasa i społeczeństwo, Warszawa 1974, s. 35 za: J. Stoetzel, Functions de la presse a cote de l' information, „Etudes de presse” 1951, nr 1, s. 86.
} 


\begin{tabular}{|c||}
\hline Funkcje mediów lokalnych \\
\hline wszechstronna informacja lokalna \\
\hline pełnienie funkcji „trybuny społeczności lokalnej”, \\
\hline integracja środowiska lokalnego \\
\hline kształtowanie lokalnej opinii społecznej \\
\hline kontrola władz lokalnych \\
\hline integracja regionalna \\
\hline wspieranie lokalnej kultury \\
\hline promocja inicjatyw lokalnych ,małej ojczyzny” \\
edukacja \\
\hline rozrywka \\
\hline
\end{tabular}

Choćby pobieżny przegląd tego zestawienia wskazuje wyraźnie na ważne dla funkcjonowania społeczności lokalnych przeznaczenie prasy samorządowej. Istotą jej misji jest ugruntowywanie w mieszkańcach ,małych ojczyzn” rzetelnej wiedzy na tematy stanowiące przedmiot zainteresowania lokalnej opinii publicznej. W tym obszarze mieści się zatem zarówno prawdziwa, sprawdzona informacja o działaniach władz (podejmowanych inicjatywach, realizowanych przedsięwzięciach, skutkach wcześniejszych decyzji), jak i reprezentowanie w publikacjach tych wszystkich członków wspólnoty gminnej, którzy - z różnych zresztą powodów - w starciu z machiną biurokracji nie potrafią skutecznie zadbać o własne interesy. Niezwykle ważną funkcją mediów lokalnych, choć równie trudną do realizacji w przypadku biuletynów samorządowych, jest kontrola poczynań władz samorządowych. Specyficzne, wiernopoddańcze relacje pomiędzy przedstawicielami gremiów decydenckich a członkami redakcji w połączeniu z brakiem świadomości zawodowej, charakterystycznej dla środowiska dziennikarzy mediów ogólnokrajowych, uniemożliwiają w praktyce wywiązywanie się $\mathrm{z}$ tej powinności. Efektem uprawiania „dziennikarstwa na kolanach” jest pozbawienie biuletynów samorządowych jakichkolwiek krytycznych treści odnoszących się do działań osób aktualnie sprawujących w gminie rządy, co nie bez powodu do złudzenia przypomina znane z minionego systemu politycznego czasy ,propagandy sukcesu”. Bez wypełniania tych powinności - informacyjnej, sprawowania funkcji „trybuny społeczności lokalnej” oraz kontrolnej - niezwykle trudne wydaje się należyte realizowanie w praktyce pozostałych. Na ile bowiem możliwa jest integracja środowiska lokalnego bez prawdziwej, często krytycznej wobec szkodliwych, nieracjonalnych lub wręcz patologicznych działań władz informacji? Czy w takim przypadku funkcja kształtowania pluralistycznej opinii publicznej ma jeszcze rację bytu, skoro adresaci przekazów pozbawieni są ważnych treści, stanowiących niezbędną przesłankę do wyrobienia sobie zdania na tematy dotyczące społeczności „małej ojczyzny” i podejmowanych później decyzji? Jak w pełni realizować funkcję promocji inicjatyw lokalnych, skoro na łamy biuletynów samorządowych nie moga przebić się informacje o tego typu przedsięwzięciach firmowanych przez miejscowe organizacje pozarządowe uznawane często przez sprawujących władzę za ,niekonstruktywną” opozycję, a w najlepszym przypadku za szkodliwą konkurencję?

Miejsce wskazanych powyżej powinności przypisywanych prasie lokalnej, w tym samorządowym biuletynom informacyjnym, zaczęła zajmować funkcja propagandowa. Działania określane tym mianem stały się, w sposób mniej lub bardziej świadomy, treścią pracy osób re-

\footnotetext{
${ }^{5}$ W. Chorązki, Obraz niezależnej prasy lokalnej w Polsce w I połowie 1994 roku, Kraków 1994, s. 17 i n.
} 
dagujących owe periodyki. Propaganda doczekała się literaturze przedmiotu licznych i zróżnicowanych definicji, z których na potrzeby niniejszej publikacji autor przywoła kilka. Institut of Propaganda Analysis w 1937 roku stwierdził, że propaganda to:

wyrażanie opinii i podejmowanie działań przez poszczególne osoby lub grupy ludzi z myśla o uksztaltowaniu opinii i podejmowanie działań przez inne jednostki i grupy dla osiagnięcia celu ${ }^{6}$.

Jacques Ellul określił charakter tego typu działań jako

zespót metod stosowanych przez zorganizowane grupy w celu wciagnięcia do aktywnego lub biernego uczestnictwa mas ludzkich, u których $w$ konsekwencji manipulacji psychicznej, wytwarza się jedność psychiczna pozwalajaca na właczenie ich do masowych działan'

Jeszcze prościej specyfikę tego typu oddziaływań zdefiniował Lindley M. Fraser, według którego

propagandę można zdefiniować jako sztukę zmuszania ludzi do robienia tego, czego by nie robili, gdyby dysponowali wszystkimi danymi dotyczacymi sytuacji ${ }^{8}$.

W podobny sposób odnieśli się do tego zjawiska Garth S. Jowett i Victoria O`Donell:

propaganda jest celowa $i$ systematyczna próba kształtowania percepcji, manipulowania myślami i bezpośrednimi zachowaniami $w$ celu osiagnięcia takich reakcji, które sq zgodne z pożadanymi intencjami propagandzisty ${ }^{9}$.

Specyfika tego typu oddziaływań w praktyce funkcjonowania biuletynów samorządowych musiała wpłynąć na charakter relacji pomiędzy członkami redakcji a decydentami politycznymi, prowadząc z reguły do wyraźnego ograniczenia ich samodzielności. Ilustrują to doskonale modele kierowania periodykami tego segmentu prasy, opisane przez Stanisława Michalczyka.

Modele kierowania pismami samorządów terytorialnych ${ }^{10}$

\begin{tabular}{|c|c|c|}
\hline Dyrektywno-cenzorski & Doradczo-konsultacyjny & Liberalno-partnerski \\
\hline $\begin{array}{l}\text { Władze lokalne sprawują } \\
\text { bezpośredni nadzór } \\
\text { nad wydawnictwem }\end{array}$ & $\begin{array}{l}\text { Duża swoboda dziennikarzy w doborze } \\
\text { materiałów }\end{array}$ & $\begin{array}{l}\text { Duży zakres swobody zespołów redak- } \\
\text { cyjnych }\end{array}$ \\
\hline $\begin{array}{l}\text { Wpływają na jego zawartość } \\
\text { Wpływają na sposób } \\
\text { przygotowania materiałów } \\
\text { (wstępna selekcja materiałów } \\
\text { do druku oraz cenzurowanie } \\
\text { tekstów dziennikarskich) }\end{array}$ & $\begin{array}{l}\text { Konsultacje z przedstawicielami władz } \\
\text { lokalnych dotyczące zawartości i treści } \\
\text { publikacji }\end{array}$ & $\begin{array}{l}\text { Władze lokalne nie ingerują w zawar- } \\
\text { tość pisma i treść konkretnych publikacji }\end{array}$ \\
\hline
\end{tabular}

${ }^{6}$ O. Thomson, Historia propagandy, Warszawa 2001, s. 10.

${ }^{7}$ J. Ellul, Propaganda. The Formation of Men's Attitudes, New York 1965, s. 61. W oryginale J. Ellul pisał: Propaganda is a set of methods employed by an organized group that wants to bring about the active or passive participation in its actions of a mass of individuals, psychologically unified through psychological manipulations and incorporated in an organization.

${ }^{8}$ L. M. Fraser, Propaganda, London 1957.

${ }^{9}$ G. S. Jowett, V. O’Donnell, Propaganda and Persuasion, Beverly Hills 1986.

${ }^{10}$ S. Michalczyk, Prasa samorzadowa. Szkice prasoznawcze, Katowice 1996, s. 37. 
Obserwacje biuletynów samorządowych wskazują niezbicie na dominującą pozycję modelu dyrektywno-cenzorskiego, który w największym stopniu uzależnia członków redakcji od wytycznych politycznych dysponentów. Jest wyrazem niezrozumienia przez przedstawicieli gminnych elit istoty demokratycznego komunikowania, w którym wolność informacji nie może podlegać żadnym (poza rzecz jasna wynikającymi z przepisów prawa) ograniczeniom. Ten charakter oddziaływań czyni z członków redakcji bezwolnych wykonawców odgórnych poleceń, a nawet w niektórych sytuacjach uwarunkowanych instytucjonalnie interpretatorów rzeczywistości.

Pisma samorzqdowe niejako z definicji biorq sobie bowiem za cel ksztattowanie jak najkorzystniejszego obrazu sytuacji społeczno-politycznej panujacej na obszarze ich funkcjonowania. W konsekwencji, z publicznych pieniędzy utrzymywane sa periodyki, na tamach których dominuje propaganda sukcesu, natomiast tematy niewygodne dla miejscowych władz sa przemilczane lub wręcz ukrywane. Co ciekawe, lokalni decydenci $w$ wielu przypadkach nie musza nawet bezpośrednio ingerować $w$ zawartości wydawanej przez dany samorzqd gazety. Osoby przygotowujace takie periodyki często same staraja się bowiem redagować je $w$ taki sposób, by przypodobać się miejscowym urzędnikom, którzy sq jednocześnie ich przełożonymi ${ }^{11}$.

W ten sposób powstaje i utrwala się formalny układ zależności wpływający na deformację treści upowszechnianych tym kanałem przekazu. Jego funkcjonowanie dla sporej części nieświadomych charakteru tych oddziaływań odbiorców bywa zgubne. Oczekując rzetelnej informacji o najważniejszych dla społeczności lokalnej problemach nie zdają sobie najczęściej sprawy z tego, że są celem oddziaływań propagandowych niemających nic wspólnego z ideą wiernego odzwierciedlania rzeczywistości w mediach. Niewiedza w zakresie technik stosowanych $\mathrm{w}$ takich sytuacjach potęguje efekty $\mathrm{w}$ zakresie manipulacji, czyniąc $\mathrm{z}$ poszczególnych odbiorców niemal zupełnie bezbronne jednostki. A wachlarz wykorzystywanych w biuletynach samorządowych metod dezinformacji bywa zaskakująco bogaty.

\begin{tabular}{||l|l||}
\hline \multicolumn{2}{|c||}{ Techniki propagandowe stosowane w biuletynach samorządowych } \\
\hline Powtarzania & treści mają przekonać adresatów i zapaść im głęboko w pamięć \\
\hline Przemilczania & pomija się pewne kategorie informacji (np. o sukcesach opozycji) \\
\hline Selekcji & $\begin{array}{l}\text { dobór faktów i informacji prowadzi do stronniczej eliminacji pewnych ,,wstydliwych” } \\
\text { wydarzeń ze świadomości lokalnej opinii publicznej dotyczących działalności władz } \\
\text { (błędne decyzje, niegospodarność, patologiczne zachowania decydentów) }\end{array}$ \\
\hline Nadmierne uogólnianie & $\begin{array}{l}\text { z reguły prowadzi do tworzenia mitów na temat władzy lub opozycji, z którymi nie dys- } \\
\text { kutuje się (np. „powszechnie wiadomo”) }\end{array}$ \\
\hline Autorytetu & $\begin{array}{l}\text { cytowanie gminnych notabli nawet wówczas, gdy nie mają kompetencji w danej dzie- } \\
\text { dzinie, aby potwierdzić treść propagandową }\end{array}$ \\
\hline Kreowania wroga & $\begin{array}{l}\text { jest nim każdy, kto ośmieli się krytykować aktualną władzę, przy czym w publikacjach } \\
\text { próbuje się z niego uczynić wroga nie tylko samych rządzących, ale całej społeczności }\end{array}$ \\
\hline Ośmieszania opozycji & $\begin{array}{l}\text { próba deprecjonowania powagi członków mniejszości w gremiach rządzących prowa- } \\
\text { dzi do wykorzystywania prostych środków obniżających pozycję takich osób (w publi- } \\
\text { kacjach pojawia się zatem np. „pan Mietek” zamiast „,radny Mieczysław Kowalski”, } \\
\text { „nasz roztropny wójt” kontra „,oszołomy” itd.) }\end{array}$ \\
\hline
\end{tabular}

${ }^{11}$ J. Parnes, http://samorzady.polska.pl/goracytemat/article,Lokalna_prasa_a_samorzady,id,361549.htm. 


\begin{tabular}{||l|l||}
\hline $\begin{array}{l}\text { Nadreprezentacji } \\
\text { wizerunku }\end{array}$ & $\begin{array}{l}\text { przedstawiciele elity władzy nie tylko mają swoje stałe rubryki w biuletynie gminnym } \\
\text { (których z reguły nie mają przedstawiciele opozycji lub ,niekonstruktywnych” organi- } \\
\text { zacji pozarządowych), ale dodatkowo ich wizerunek pojawia się wielokrotnie w każ- } \\
\text { dym numerze czyniąc z nich lokalnych celebrytów uczestniczących w różnego typu } \\
\text { uroczystościach }\end{array}$ \\
\hline Dezinformacja & $\begin{array}{l}\text { w redagowaniu tekstów wykorzystuje się zróżnicowane techniki służące manipulacji } \\
\text { faktami, np. negację faktów, odwrócenie faktów, kamuflaż, mieszaninę prawdy i kłam- } \\
\text { stwa }\end{array}$ \\
\hline
\end{tabular}

Zastosowanie tych technik w połączeniu z niechlubną praktyką cenzurowania treści publikacji niedających pogodzić się z interesem decydenta politycznego redukuje w efekcie dostęp obywateli do rzetelnej informacji i pluralistycznych opinii na dany temat. Taki stan rzeczy sprawia, że członkowie lokalnych społeczności często dowiadują się o ważnych decyzjach zapadających w ich sprawach już po czasie, gdy procedury zostały wdrożone, a czas na ewentualne odwołania do stosownych instytucji dawno minął. Wywołuje to, co naturalne, negatywne emocje w ramach wspólnoty samorządowej, które niejednokrotnie prowadzą do konfliktów obywateli z władzą. Dodatkowym skutkiem jest spadająca wiarygodność tego typu publikatorów gminnych, w których czytelnik na ogół nie znajdzie treści poruszających kluczowe kwestie dotyczące lokalnych społeczności oraz krytycznych opinii wyrażanych przez osoby lub organizacje spoza grona aktualnie sprawującego władzę establishmentu. Rodzi to uzasadnione przekonanie o dużym stopniu uzależnienia redakcji biuletynów samorządowych od rządzących, a przez to obniża zaufanie odbiorców do przekazywanych tą drogą treści. Doskonale ilustruje tę tendencję poniższy wykres, pokazujący udział procentowy periodyków samorządowych w grupie tytułów uznawanych za niezależne.

\section{Wydawcy - właściciele periodyków}

(na podstawie kwestionariusza wysłanego do niezależnych periodyków)

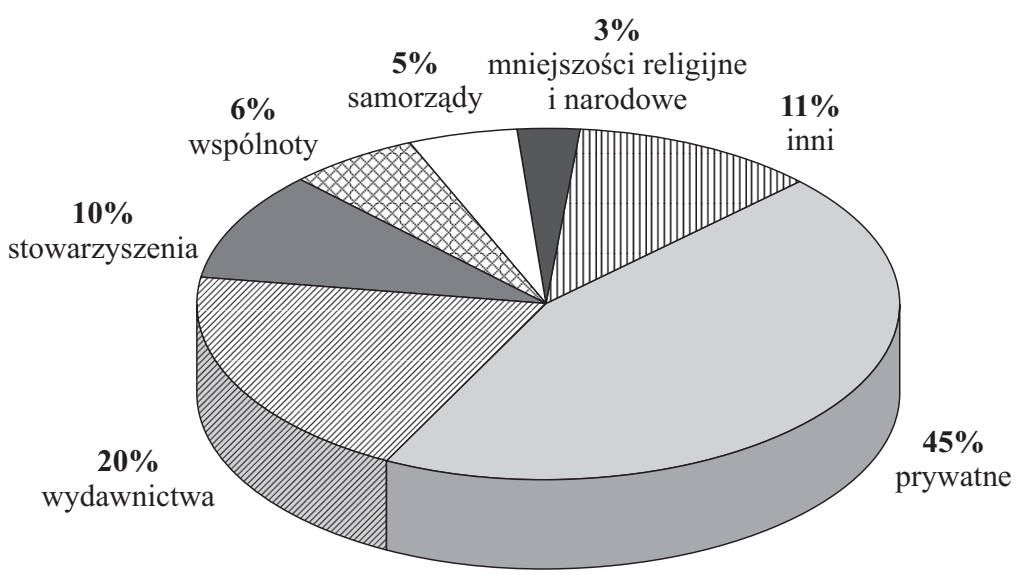

Źródło: How To Establish The Independence Of The Regional Press. Activity Proposal, The Institute for Democracy In Eastern Europe Foundation (IDEE), Warsaw 1995.

Powyższa ilustracja dotyczy sytuacji na rynku prasy lokalnej w ciaggu pierwszych pięciu lat od restytucji samorządu terytorialnego na poziomie gmin. Upływ lat, wbrew oczekiwaniom, nie odwrócił tej niepokojącej tendencji. W badaniach prowadzonych przez IDEE, których wyniki autor przywołuje w niniejszej publikacji, zwrócono uwagę na warunki nie- 
zbędne do uzyskania statusu pisma niezależnego. Wśród kluczowych znalazła się finansowa niezależność, która w przypadku biuletynów samorządowych jest mitem. Ścisłe zależności wynikające z powiązań ekonomicznych (o czym będzie jeszcze mowa w dalszej części rozważań) są poważnym balastem dla redakcji tego segmentu prasy lokalnej. Jest on bowiem uzależniony $\mathrm{w}$ równym stopniu poprzez dotacje $\mathrm{z}$ gminnych budżetów, jak i wynagrodzenia stanowiące świadczenia z tytułu wykonywanej pracy w charakterze urzędnika gminnego lub pracownika podległej samorządowi jednostki. Za nie mniej istotne uznano ,niezależne widzenie spraw”, ,pluralizm dziennikarzy” oraz „niezależność dziennikarzy”. Warunki te pozostają jednak w odniesieniu do biuletynów samorządowych nieosiagalne w praktyce. Trudno bowiem wymagać od autorów publikacji tam pomieszczanych niezależności czy takiegoż prezentowania spraw, gdy są oni na co dzień podwładnymi decydentów politycznych owych pism. Deficytowym dobrem w działalności biuletynów samorządowych są również przywoływane w cytowanym badaniu ,brak powiązań między wydawcą a władzami” (w tym przecież przypadku to przecież ten sam podmiot) czy „odporność dziennikarzy na naciski z zewnątrz" (ten warunek redukują niemal do minimum zależności ekonomiczne, związki na linii pracodawca-pracownik, towarzyskie, biznesowe, a nawet często rodzinne).

Warunki, które muszą być spełnione, aby uważać pismo lokalne za niezależne (dotyczy grupy pism zmierzających do niezależności)

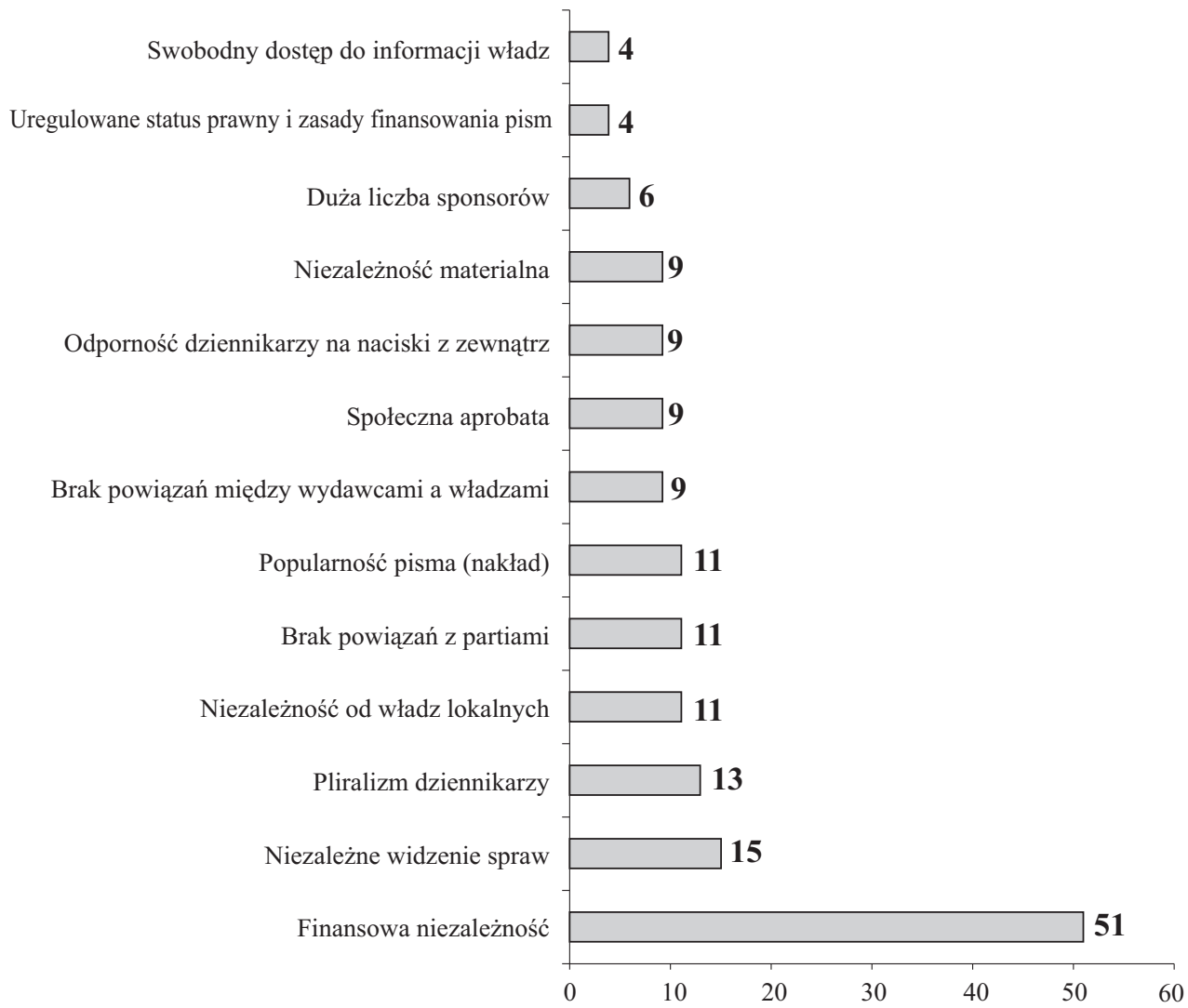

Źródło: How To Establish The Independence Of The Regional Press. Activity Proposal, The Institute for Democracy In Eastern Europe Foundation (IDEE), Warsaw 1995. 
Doświadczenia minionych dwóch dekad oraz poczynione w tym czasie obserwacje nie pozostawiają złudzeń co do faktycznego przeznaczenia publikatorów funkcjonujących w tym segmencie prasy lokalnej.

Zwiazki mediów lokalnych $z$ władzq samorzqdowa $w$ drugiej kadencji miaty bardziej uregulowany charakter, lecz zbyt wiele nie zmieniło się. Włodarze i radni nie rezygnowali tatwo z ręcznego sterowania podległymi im redakcjami. Wszelkie odgórne głosy krytyki tego stanu rzeczy ze strony ogólnopolskich mediów nie przynosity poprawy. Wiadomym byto, że samorzadowcy przygotowywali sobie wyborców do „,właściwych decyzji "12.

Rozmiary tego zjawiska, biorąc przede wszystkim pod uwagę liczebność tytułów tego typu prasy, są poważne. Według danych Ośrodka Badań Prasoznawczych UJ w Krakowie w 2005 r. ogółem odnotowano 2597 tytułów prasy lokalnej i sublokalnej, z tego 39,12 procent stanowiły pisma samorządowe, a 37,74 procent prywatne ${ }^{13}$. Oznacza to zatem liczebną przewagę biuletynów samorządowych nad komercyjnymi i w dużej mierze niezależnymi od lokalnych władz tytułami prasowymi. Nowsze badania wskazują jeszcze dobitniej, jak wielką wagę samorządowcy przywiązują do posiadania kontrolowanych przez siebie kanałów przekazu.

\section{Liczba samorządów, które zdecydowały się wydawać tytuł prasowy}

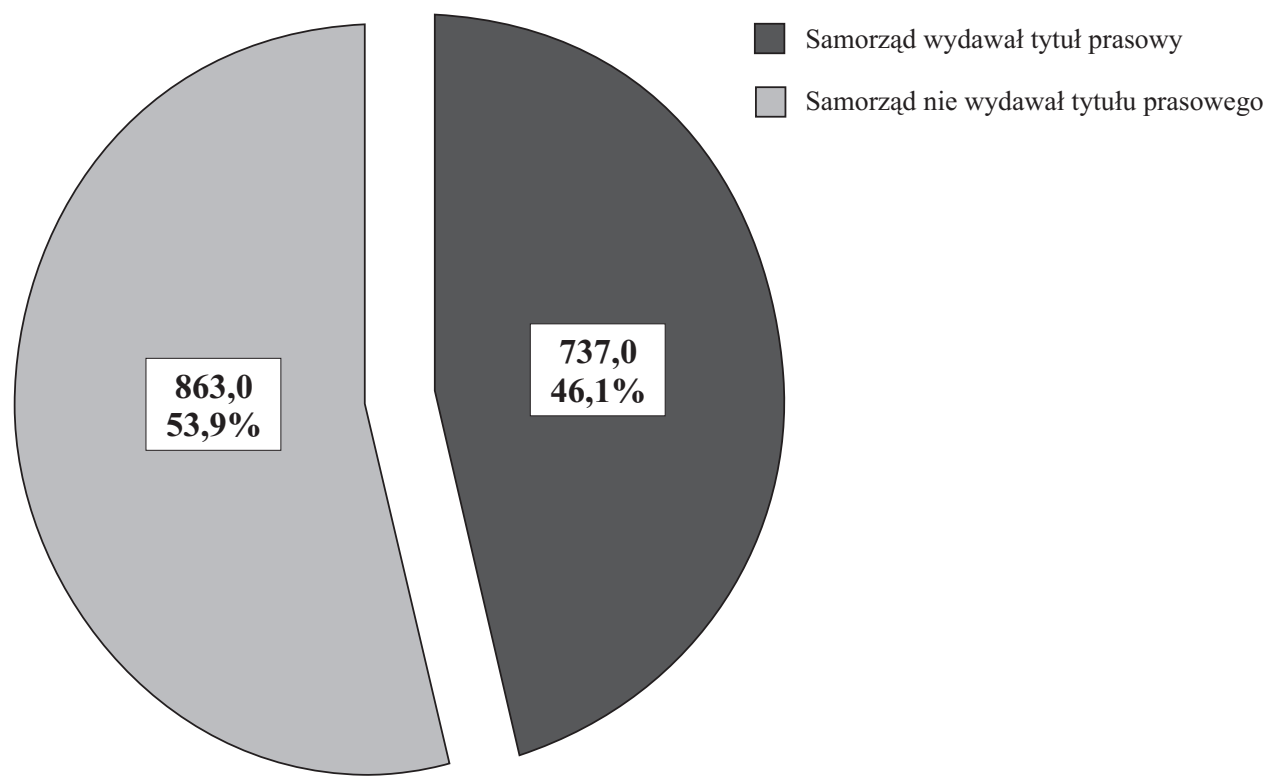

Źródło: Centrum Monitoringu Wolności Prasy Stowarzyszenia Dziennikarzy Polskich, Badanie prasy samorzqdowej, Warszawa 2009.

12 A. K. Piasecki, Samorząd terytorialny a media lokalne (1990-2002), „Zeszyty Prasoznawcze” Kraków 2003, nr $1-2$.

${ }^{13}$ A. Gruchot, Polska prasa lokalna. Sytuacja bieżaca, podstawowe problemy, perspektywy, Izba Wydawców Prasy, Warszawa 2008, s. 2 (materiał przedłożony na posiedzenie Sejmowej Komisji Kultury i Środków Przekazu nt. „Sytuacja prasy lokalnej” 19 listopada 2008 r.). 
Aspiracje do posiadania własnego tytułu gminnego, wyrażone w liczbach bezwzględnych, stanowią dowód nie tylko na duże zapotrzebowanie samorządowców w dziedzinie komunikowania. Nade wszystko są one zaskakujące, szczególnie przy uwzględnieniu braku wykształcenia dziennikarskiego i niezbędnego doświadczenia w działalności wydawniczej na rynku mediów, charakteryzujących ogromną rzeszę funkcjonariuszy publicznych na szczeblu samorządu gminnego. Prezentowana przez nich wizja funkcjonowania biuletynu samorządowego rozmija się w większości przypadków z oczekiwaniami społeczności lokalnych oraz ideą demokratycznego dyskursu publicznego. W efekcie wytwory pracy podległych im urzędników-dziennikarzy nie wychodzą poza ramy typowo propagandowych publikatorów. Dodatkowym problemem są w tym kontekście wydatki ponoszone przez samorządy lokalne na działalność wydawniczą. Przeznaczane z gminnego budżetu fundusze stanowią na ogół darmową formę promocji lokalnych notabli, którzy bez skrupułów wykorzystują tę formę politycznej reklamy do zabiegania o głosy wyborców w kolejnych wyborach.

Wydatki samorządów na publikacje w pismach zewnętrznych w pierwszym półroczu 2007 roku

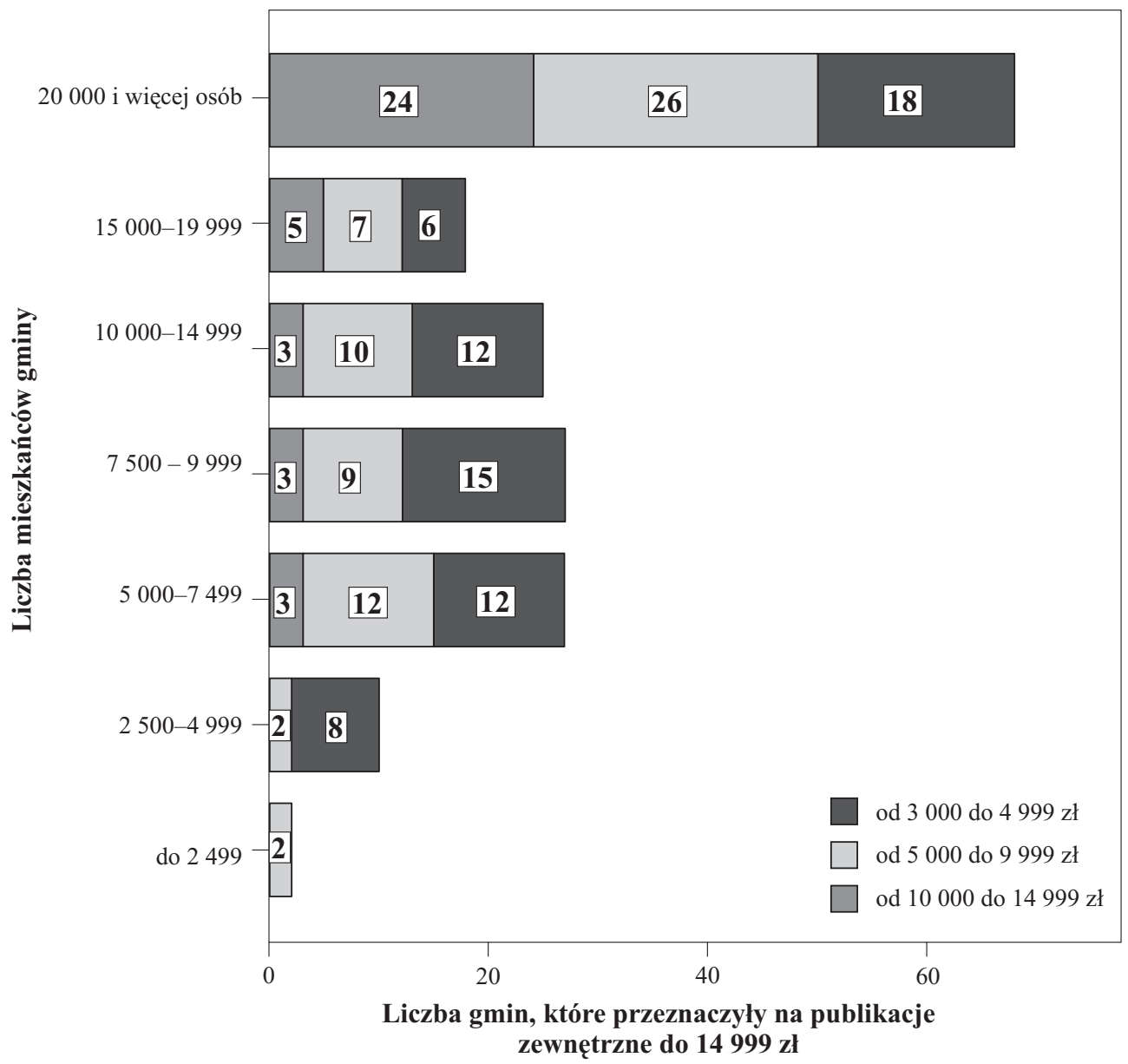

Źródło: Centrum Monitoringu Wolności Prasy Stowarzyszenia Dziennikarzy Polskich, Badanie prasy samorzqdowej, Warszawa 2009. 
Warto zauważyć, że wydatki na działalność wydawniczą mogą przekroczyć kwotę 10000 złotych rocznie już w przypadku gmin liczących niespełna 5000-7500 mieszkańców. A, jak widać na wykresie, im większa gmina tym chętniej przeznacza wyższe kwoty na sfinansowanie publikacji. Fundusze wyasygnowane na działalność wydawniczą mogą wśród części jednostek samorządowych być znacznie wyższe, co ilustruje kolejny wykres. Oczywiście kwoty rzędu kilkudziesięciu tysięcy złotych odniesione do budżetów gminnych osiągających poziom rocznych dochodów liczonych w dziesiątkach milionów złotych wydają się sumą niewielką, jednak budzący zasadne kontrowersje sposób ich przeznaczenia rodzi pytania co do racjonalności takiego postępowania. Od dysponujących pieniądzem publicznym samorządowców obywatele mają prawo wymagać takiego działania, które nie pozostaje w sprzeczności z interesem społeczności lokalnych, a wręcz przyczynia się do budowania podstaw społeczeństwa obywatelskiego, w którym rzetelna, dostępna i zróżnicowana informacja stanowi nieodłączny element współżycia społecznego.

Wydatki samorządów na publikacje w pismach zewnętrznych w pierwszym półroczu 2007 roku

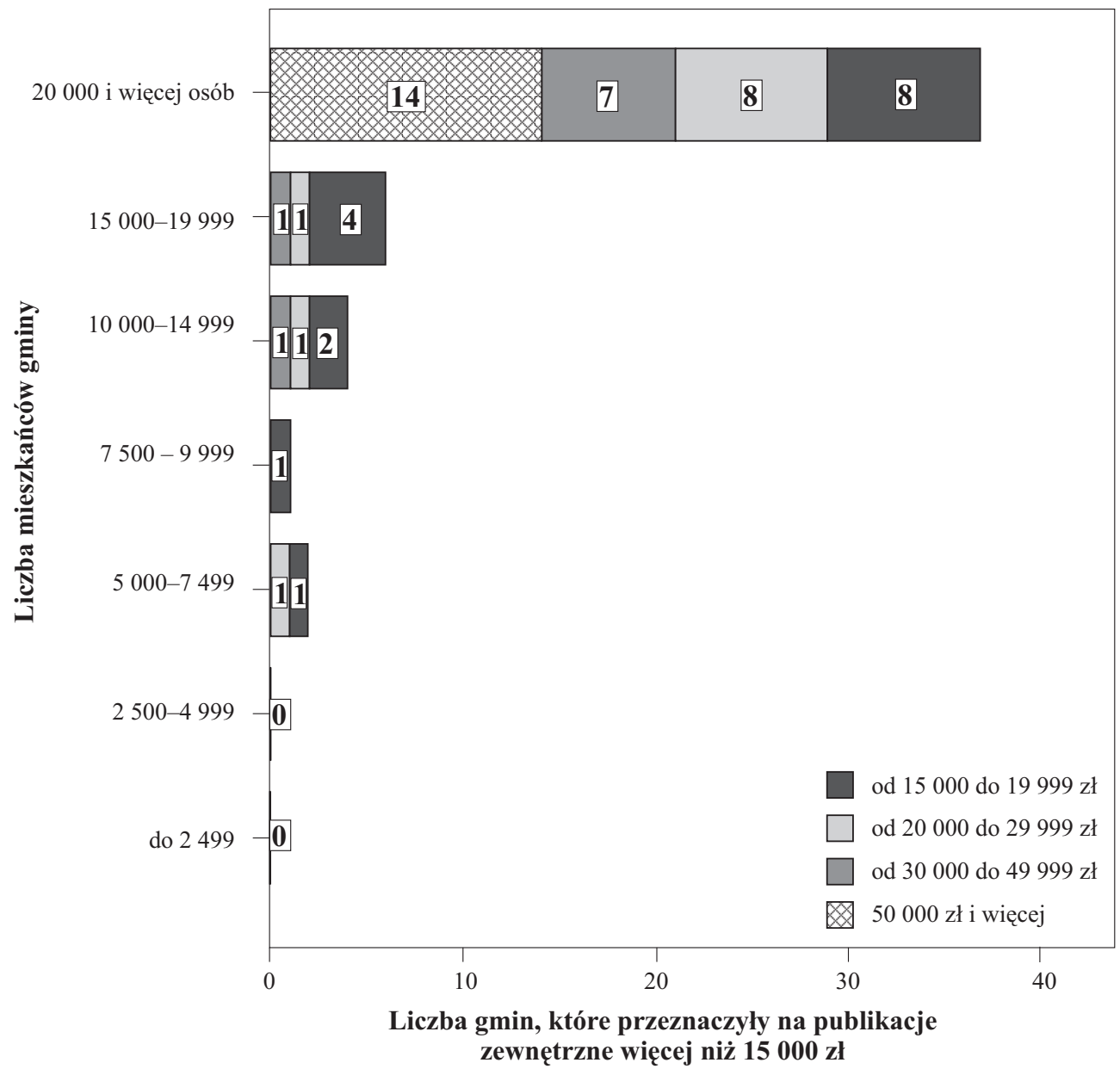

Źródło: Centrum Monitoringu Wolności Prasy Stowarzyszenia Dziennikarzy Polskich, Badanie prasy samorzadowej, Warszawa 2009. 
Interesująco przedstawiają się również wyniki cytowanego badania w zakresie podejmowania przez samorząd terytorialny wysiłku bycia samodzielnym wydawcą biuletynu informacyjnego. Z 737 jednostek samorządowych, które zdecydowały się na tego typu działalność wydawniczą większość, bo aż 607 występuje w charakterze wydawcy. Jest to, co zostało już wcześniej podkreślone, zastanawiająca forma aktywności ze strony organów władzy publicznej, której powołaniu do życia towarzyszyło zupełnie inne przeznaczenie. Wspomniany brak odpowiedniego przygotowania merytorycznego oraz doświadczenia w branży medialnej nie przeszkadza jednak wielu samorządowcom w prowadzeniu tego typu aktywności, nawet wobec zarzutów o stronniczość wydawanych przez nich publikatorów i niski poziom profesjonalizmu. Można zatem domniemywać, że nadrzędny cel przyświecający rządzącym stanowi większą wartość od zachowania bezstronności w formułowaniu ocen na temat działań władz lokalnych. Jak nie trudno się domyślić, taka formuła wydawnicza daje ekipie sprawującej władzę nieograniczone możliwości wpływania na zawartość przekazu, zamieszczane informacje i ferowane opinie. W konsekwencji jednak prowadzi do zawłaszczenia istotnej części sfery dyskursu publicznego, w której niewłaściwie redagowane, a tym samym znacznie bardziej uzależnione biuletyny samorządowe nie mogą odegrać ważnej roli. Łatwe do przewidzenia są również reakcje kolejnych ekip rządzących, które po wyborach przejmując władzę odreagowują wcześniejszą marginalizację swoich poglądów poprzez mniej lub bardziej świadome naśladowanie poprzedników w tej dziedzinie.

Wydatki samorządów na publikacje w pismach zewnętrznych w pierwszym półroczu 2007 roku

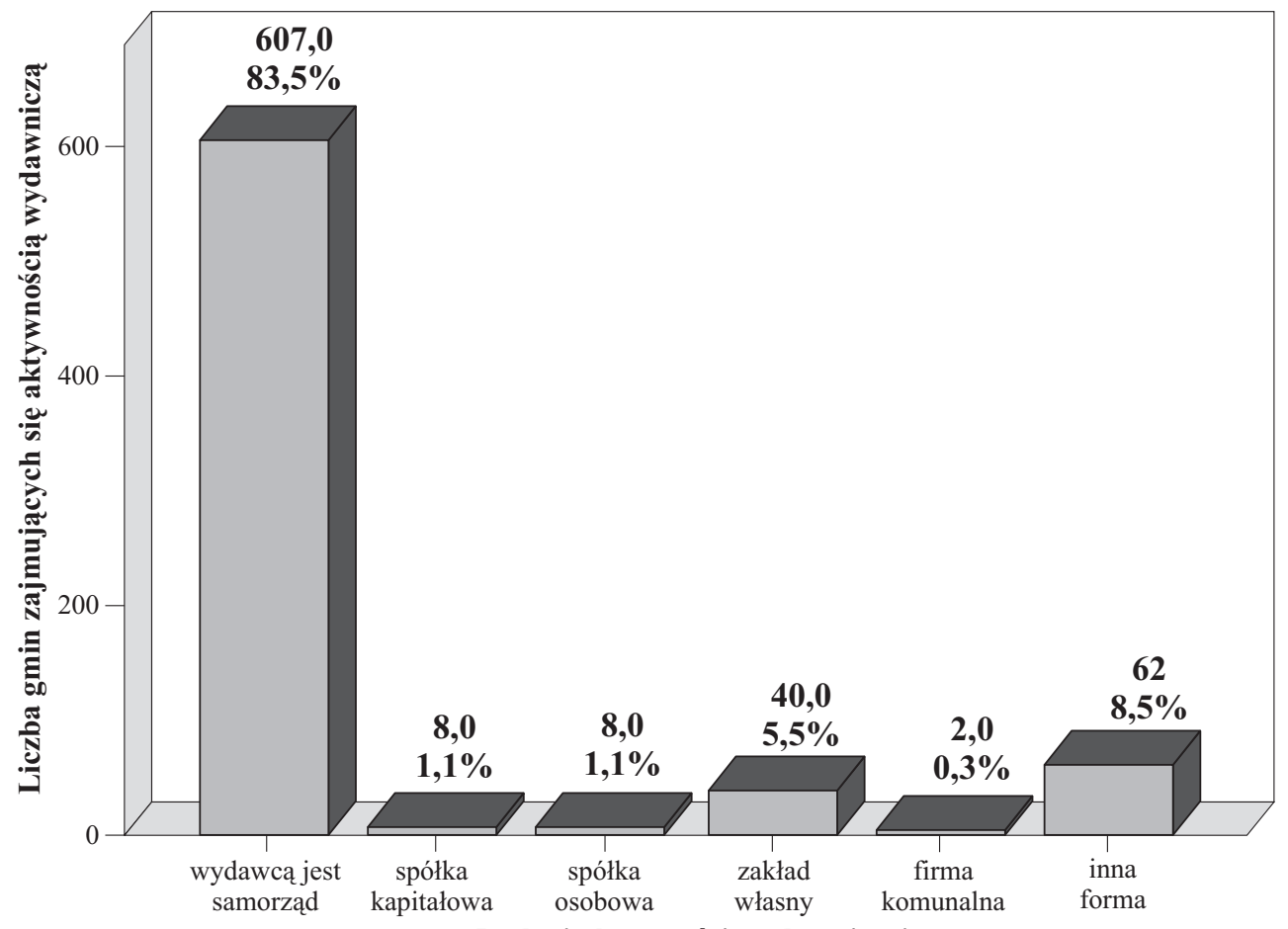

Rodzaj aktywności wydawniczej

Źródło: Centrum Monitoringu Wolności Prasy Stowarzyszenia Dziennikarzy Polskich, Badanie prasy samorzqdowej, Warszawa 2009. 
Sytuacja w tym segmencie mediów znalazła odbicie w dyskusji toczonej od kilku lat na forum złożonym z przedstawicieli organów ustawodawczych, wykonawczych, naukowców oraz wydawców i dziennikarzy prasy lokalnej. We wrześniu 2004 roku Izba Wydawców Prasy przy współudziale Senackiej Komisji Kultury i Środków Przekazu, zorganizowała konferencję na temat „Prasa lokalna w budowie społeczeństwa obywatelskiego”. Uczestnicy konferencji przyjęli stanowisko, w którym poruszono sprawę występowania samorządów w roli wydawców prasy. Czytamy w nim:

Szczególna uwage społeczeństwa oraz właściwych organów ustawodawczych $i$ administracyjnych uczestnicy Konferencji pragna zwrócić na niewtaściwość i szkodliwość zjawiska polegajacego na coraz częstszym występowaniu samorzadów lokalnych $w$ roli wydawców prasy. Zdaniem uczestników Konferencji nie należy łaczyć funkcji biuletynu informacyjnego - organu administracji z funkcja niezależnej prasy, której wszak jednym $z$ głównych zadań jest sprawowanie społecznej kontroli nad działaniami władz. Uzurpowanie sobie przez biuletyny samorzadowe roli gazet wiaże się niejednokrotnie z utrudnianiem dostępu do informacji dziennikarzom prasy prywatnej, co jest podważaniem fundamentalnej zasady wolności słowa i prawa obywateli do dostępu do informacji ${ }^{14}$.

W cytowanym dokumencie zwrócono również uwagę na inne ważne aspekty tej aktywności samorządów lokalnych. Podniesiona została między innymi kwestia łączenia przez wydawców pism samorządowych funkcji publicznych z działalnością gospodarczą.

Korzystanie ze środków publicznych i prowadzenie działalności biznesowej rodzi liczne watpliwości natury formalnej i etycznej, a także zgodności z zasadami uczciwej konkurencji. Szczególnie pozyskiwanie reklam przez „,gazety” samorzqdowe od firm zależnych od władzy lokalnej sprzyja możliwości powstawania na lokalnych rynkach sytuacji korupcjogennych ${ }^{15}$.

Finansowanie działalności biuletynów samorządowych odbywa się w wielu przypadkach dwutorowo. $\mathrm{Z}$ jednej strony periodyki te dotowane są przez władze lokalne $\mathrm{z}$ gminnych budżetów (kwoty zależą z reguły od wielkości dochodów jednostki samorządowej oraz zapotrzebowania na promowanie własnych zasług wśród obywateli). Fundusze te przeznaczane są na opłacenie zewnętrznych firm zajmujących się składem i drukiem. Drugim źródłem finansowania są przychody z reklam, często wielokrotnie przewyższające wysokość dotacji. Wpływy te zasilają czasami wspomniane firmy zewnętrzne, które zajmują się również akwizycją reklam i ogłoszeń. Ten system uwalnia władze lokalne od konieczności zajmowania się techniczną stroną produkcji biuletynu i pozwala skupić uwagę na zawartości przekazu. Rodzi jednak dwuznaczne sytuacje na styku władza - prywatne podmioty gospodarcze. Te ostatnie stają się ,zakładnikiem” układu z władzą, bowiem bez regularnego zlecania reklam w biuletynie samorządowym maleje szansa na realizację planowanych inwestycji. Godząc się na takie rozwiązanie lokalni przedsiębiorcy wspierają nieformalnie działalność elit władzy i finansują $\mathrm{w}$ dużym stopniu treści o charakterze propagandowym (przy ograniczonych wpływach z reklam biuletyny miałyby uboższą szatę graficzną, niższe nakłady oraz mniejszą objętość, co zmusiłoby samorządy do zmodyfikowania formuły lub zwiększenia dotacji z budżetu, choć to drugie rozwiązanie wydaje się mało prawdopodobne). Jednocześnie rośnie presja władz na

\footnotetext{
${ }^{14}$ Stanowisko Konferencji Senatu RP i Izby Wydawców Prasy z dnia 21 września 2004 r. w sprawie zagrożeń funkcjonowania prasy lokalnej.

${ }^{15}$ Ibidem.
} 
pomijanie w budżetach reklamowych miejscowych podmiotów gospodarczych konkurencyjnych tytułów prasy komercyjnej lub wydawanych przez organizacje pozarządowe.

Do najpopularniejszych form represji wobec ,niepokornych” tytułów lokalnych należy obłożenie redakcji danej gazety embargiem na dostęp do informacji oraz wstrzymanie publikowania na jej łamach płatnych ogłoszeń samorzqdowych. Lokalni urzędnicy niekiedy wymuszaja również na miejscowych podmiotach gospodarczych zaprzestanie umieszczania reklam $w$ określonych periodykach, szantażując przedsiębiorców groźba bojkotowania ich firm $w$ publicznych przetargach lub sabotowania ich działalności nieustannymi kontrolami różnego rodzaju służb podległych samorzqdom (np. inspekcje sanitarno-epidemiologiczne, kominiarskie itp.). Do rzadkości nie należy także eksmitowanie redakcji z lokalu wynajmowanego przez nia od gminy lub powiatu. $W$ skrajnych sytuacjach dochodzi nawet do wyrzucania z pracy tych dziennikarzy $i$ członków ich rodzin, którzy zatrudnieni sq $w$ podległych samorzqdowi instytucjach ${ }^{16}$.

Te praktyki od lat wzbudzają sprzeciw wydawców prasy lokalnej działających na zasadach komercyjnych lub non profit. 29 października 2009 r. w Krakowie odbyła się konferencja pt. „Wolność słowa w prasie lokalnej. Prasa lokalna a normy ochrony konkurencji i pluralizm medialny", zorganizowana przez Izbę Wydawców Prasy wspólnie z Obserwatorium Wolności Mediów w Polsce Helsińskiej Fundacji Praw Człowieka. Uczestnicy podjęli w czasie obrad szereg kwestii bulwersujących właścicieli lokalnych mediów. Wnioski płynące $\mathrm{z}$ dyskusji znalazły się w treści listu skierowanego na ręce Premiera Donalda Tuska w styczniu 2010 roku. Podniesiono w nim ponownie kwestię niewłaściwych reguł funkcjonowania periodyków samorządowych, będących skutkiem rozmaitych zależności na linii władze lokalne - redakcja oraz władze lokalne - przedsiębiorcy.

Jednym z najważniejszych zadań prasy lokalnej jest petnienie społecznej kontroli nad poczynaniami władz lokalnych, prezentowanie jej sukcesów, wyjaśnianie problemów i tworzenie więzi społeczeństwa lokalnego z jego reprezentantami. Aby jednak niezależna prasa lokalna mogła właściwie spetniać swe zadania, w szczególności owa funkcje spolecznej kontroli administracji państwowej i samorzadowej, nie powinna napotykać na przeszkody $w$ działalności, będace skutkiem wydawania przez władze administracyjne i samorzadowe periodyków, przypisujacych sobie cechy i funkcje przynależne prasie. [...] Izba Wydawców Prasy pragnie jednak po raz kolejny zwrócić uwage na problem zacierania granicy między charakterem, działalnościq $i$ misja spoteczna wypetniana przez niezależnq, autentyczna prase a zadaniami - promocyjnymi, informacyjnymi, a nierzadko propagandowymi - wypetnianymi przez rozmaitego rodzaju biuletyny, w tym tzw. ,gazety samorzadowe "17.

Stanowisko to, korespondujące z obserwacjami przedstawionymi w niniejszym artykule, zostało wzmocnione dodatkowym postulatem. Jego realizacja doprowadziłaby mianowicie do wyeliminowania organów władz samorządowych z grona wydawców prasy. Środkiem do realizacji tego pomysłu miała być nowelizacja przepisu art. 8 ustawy Prawo prasowe.

\footnotetext{
${ }^{16} \mathrm{~J}$. Parnes, http://samorzady.polska.pl/goracytemat/article,Lokalna_prasa_a_samorzady,id,361549.htm.

${ }^{17}$ List Izby Wydawców Prasy do Premiera Donalda Tuska z dnia 20 stycznia 2010 roku. Wcześniej za takim rozwiązaniem opowiadali się wydawcy i dziennikarze reprezentujący Stowarzyszenie Prasy Lokalnej, Stowarzyszenie Gazet Lokalnych, Stowarzyszenie Polskich Mediów oraz Komisji Prasy Lokalnej Izby Wydawców Prasy, którzy spotkali się 15 listopada 2008 roku w Puszczykowie.
} 
Izba Wydawców Prasy uważa, że sytuacja opisywana przez nas wymaga uregulowań prawnych. Dobra ku temu okazja sq trwajace aktualnie prace nad nowelizacja Prawa prasowego. W projekcie nowelizacji przedstawionym przez IWP Ministrowi Kultury i Dziedzictwa Narodowego postulujemy zmianę artykutu 8, który określi kto może być wydawca prasy. Proponujemy następujace brzmienie tego artykutu:

Art. 8. 1. Wydawcq druków prasowych, agencyjnych serwisów informacyjnych oraz zarejestrowanych stron internetowych może być osoba fizyczna posiadajaca petnq zdolność do czynności prawnych, osoba prawna lub jednostka organizacyjna nie posiadajaca osobowości prawnej.

2. Organ administracji rzqdowej lub jednostka samorzqdu terytorialnego nie może być bezpośrednio lub pośrednio wydawcq, o którym mowa w ust. 1, ani posiadać udzialów lub akcji w spótkach będacych wydawcq.

3. Wydawca może powierzyć wykonywanie czynności wydawcy, z wyjatkiem powotywania redaktora naczelnego oraz podejmowania decyzji o rozpowszechnieniu publikacji innemu podmiotowi działajacemu jako nakładca ${ }^{18}$.

Rozwiązanie to, skądinąd zasadne, ma jednak swoich oponentów. Wśród nich jest między innymi prof. Michał Kulesza, który swoje stanowisko prezentował kilkakrotnie w ciagu ostatniej dekady. Jego zdaniem w obecnym porządku prawnym samorządy mają prawo do wydawania prasy lokalnej, szczególnie wtedy, gdy na rynku nie prowadzi tego typu działalności żaden inny podmiot ${ }^{19}$. Takie postawienie sprawy rodzi jednak szereg pytań. Po pierwsze, czy biuletyny samorządowe powinny w przyszłości na równych prawach z innymi mediami korzystać z nazwy prasa, szczególnie w świetle ograniczonej formuły działania? Obecny stan prawny dopuszcza takie nazewnictwo, ale przedstawione wcześniej argumenty przemawiają za podjęciem dyskusji na ten temat. Po drugie, czy nie powinno określić się w przepisach prawa dozwolonego zakresu tej formy aktywności, ograniczonego do prezentowania dokumentów prawa miejscowego przyjętego przez organy samorządowe? Analiza treści biuletynów samorządowych pokazuje, że spora liczba z nich odeszła od dokładnego publikowania treści decyzji władz lokalnych, kładąc nacisk na stronnicze omówienie wybranych aktów prawa miejscowego. Po trzecie, czy można dalej tolerować dwuznaczną sytuację wykorzystywania przez lokalnych decydentów gminnych publikatorów do prowadzenia działalności propagandowej za fundusze publiczne w imię tak zwanej działalności informacyjnej na rzecz mieszkańców? Po czwarte, czy dalsze zezwalanie na prowadzenie działalności wydawniczej przez organy władzy publicznej na poziomie samorządu nie kłóci się z wyznawaną w wielu krajach demokratycznych zasadą zakazującą prowadzenia tej formy aktywności instytucjom państwa? Zdecydowane rozstrzygnięcie tych kwestii powinno przyczynić się do zwiększenia przejrzystości aktywności władz samorządowych na polu komunikowania z wykorzystaniem istniejących kanałów przekazu oraz wykluczenia możliwości uprawiania przez lokalnych decydentów propagandy na łamach biuletynów gminnych.

\footnotetext{
${ }^{18}$ Ibidem.

${ }^{19}$ Ł. Lasek, Wolność słowa w prasie lokalnej. Prasa lokalna a normy ochrony konkurencji i pluralizm medialny, Obserwatorium wolności mediów w Polsce, http://www.regioportal.pl/pl28/teksty1692/wolnosc_slowa_w_prasie_lokalnej_prasa_lokalna_a_no.
} 


\section{ANEKS \\ Stanowisko Konferencji Senatu RP i Izby Wydawców Prasy z dnia 21 września 2004 r. w sprawie zagrożeń funkcjonowania prasy lokalnej}

Uczestnicy Konferencji „Prasa lokalna w budowie spoleczeństwa obywatelskiego”, pragna zwrócić powszechnq uwagę na wielkie znaczenie, jakie dla budowy podstaw demokracji w Polsce ma prasa lokalna. Stała się ona dla mieszkańców miast i wsi podstawowym źródtem pozyskiwania informacji o sprawach najbliższego otoczenia. Wypetnia ona również szereg funkcji kulturowych, edukacyjnych i ekonomicznych.

Prasa lokalna odgrywa również ogromna rolę $w$ kontrolowaniu władzy, ale także w prezentowaniu jej sukcesów, wyjaśnianiu problemów i tworzeniu więzi społeczeństwa lokalnego z jego reprezentantami.

Działalność lokalnych wydawców napotyka jednak liczne problemy, będace często wynikiem dajacej sięjeszcze odczuć słabości tego segmentu prasy.

$W$ warunkach zaostrzajacej się konkurencji na rynku mediów, konieczne jest:

- podnoszenie poziomu profesjonalizmu lokalnych wydawców,

— zwiększanie wiedzy fachowej dziennikarzy redagujacych gazety lokalne,

- przestrzeganie wysokich wymagań zawodowych i etycznych.

Działania te przyniosq w efekcie zwiększenie autorytetu prasy lokalnej i przyczyniq się do umocnienia jej rynkowej pozycji.

Dla wzmocnienia tego procesu niezbędne jest polepszanie techniczno-materialnych warunków wykonywania zawodu przez dziennikarzy lokalnych. Uczestnicy Konferencji widza tez potrzebe powołania zawodowej struktury dziennikarzy.

Niesprzyjajace czynniki zewnętrzne, np. niekorzystne i często niewłaściwe uregulowania prawne lub konflikty na styku prasy lokalnej z administracja państwowa, samorzadowa lub lokalnymi grupami interesów wymagaja zmian, które posłuża poprawie wspótpracy mediów z przedstawicielami administracji.

W segmencie prasy lokalnej mieszcza się też gazety zaktadane lub sponsorowane przez lokalnych polityków. Zjawisko to nasila się w każdym okresie przedwyborczym. Zdarzaja się także przypadki zakładania pism przez lokalnych biznesmenów, których głównym celem jest promocja i ochrona interesów właściciela lub sponsora. Stan ten powoduje zacieranie granic między autentyczna prasq lokalnq a pismami stużqcymi jedynie realizacji doraźnych interesów poszczególnych osób lub grup interesów i obniżaja prestiż prasy lokalnej.

Szczególnq uwage społeczeństwa oraz właściwych organów ustawodawczych i administracyjnych uczestnicy Konferencji pragna zwrócić na niewtaściwość i szkodliwość zjawiska polegającego na coraz częstszym występowaniu samorząów lokalnych $w$ roli wydawców prasy.

Zdaniem uczestników Konferencji nie należy łaczyć funkcji biuletynu informacyjnego - organu administracji z funkcja niezależnej prasy, której wszak jednym z głównych zadań jest sprawowanie społecznej kontroli nad działaniami władz. Uzurpowanie sobie przez biuletyny samorzqdowe roli gazet wiaże się niejednokrotnie z utrudnianiem dostępu do informacji dziennikarzom prasy prywatnej, co jest podważaniem fundamentalnej zasady wolności słowa i prawa obywateli do dostęu do informacji.

Poważne zastrzeżenia uczestników Konferencji budzi też taczenie przez pisma samorzqdowe funkcji publicznych z działalnościa gospodarczq. Działanie na styku wykorzystania środków publicznych i biznesu rodzi liczne watpliwości natury formalnej i etycznej oraz co do zgodności z zasadami uczciwej konkurencji. Szczególnie pozyskiwanie reklam przez „,gazety” 
samorzadowe sprzyja możliwości powstawania na lokalnych rynkach sytuacji korupcjogennych. Naraża ponadto samorzqdy na ostre konflikty z prasq lokalna, dla której przychody z reklam stanowiq podstawe ekonomicznego bytu.

Uczestnicy Konferencji apeluja do Izby Wydawców Prasy o podjęcie we wspótpracy z prasq lokalnq monitorowania przypadków naruszania prawa konkurencji przez tytuly wydawane przez samorzady lub na ich zlecenie i kierowanie tych spraw do właściwych instytucji.

Uczestnicy Konferencji postuluja wprowadzenie takich rozwiqzań prawnych, które w jednoznaczny sposób określa zasady wydawania biuletynów informacyjnych przez organa administracji $i$ samorzqdy wszystkich szczebli. Będzie to stużyto poprawie dobrze rozumianej otwartości działania administracji i samorzqdów i przyniesie wzrost zaufania społecznego do ich działalności. Jednocześnie przyczyni się to do wzmocnienia organizatorskiej funkcji autentycznej prasy lokalnej, stużqc budowaniu przez niq społeczeństwa obywatelskiego, co jest zadaniem i niezaprzeczalna zasługa tej prasy, a leży w polskim interesie narodowym.

\section{Summary}

The author points out the propagandist function as the main function of local self-government bulletins. These periodicals, published by local self-governments or their budgetary subordinates, frequently provide the main or even the only source of information about community matters, but they have transformed into a local elite's propaganda tool. Consequently, this has led to an obvious limitation in two-way social communication in smaller administrative divisions and to the development of misinformation. As attention has become focused on propagandist activity, the principal objectives of a new social system and communication between the authorities and citizens that were set twenty years ago have been neglected. The paper also discusses the attempts at imposing legal limitations on local self-government publications and initiatives undertaken in this respect. 
